\title{
Toxicity of Neem Cake Extract (Azadirachta indica) to Aphis glycine on Soybean Plant
}

\author{
Ratmaneli $^{1}$, Danar Dono ${ }^{2,3^{*}}$, Vira Kusuma Dewi ${ }^{2,3}$ \\ ${ }^{1}$ Agronomy Magister Program, Agriculture Faculty, Universitas Padjadjaran, Jatinangor, West Java, Indonesia, 45363 \\ ${ }^{2}$ Department of Plant Pests and Diseases, Agriculture Faculty, Universitas Padjadjaran, Jatinangor, West Java, Indonesia, \\ 45363 \\ ${ }^{3}$ Centre for product development and partnership study (Puspromit), Universitas Padjadjaran, Jatinangor, West Java, \\ Indonesia, 45363 \\ *Corresponding Author: danar.dono@unpad.ac.id
}

\begin{abstract}
Aphis glycine is one of the soybean pests that can develop rapidly and cause yield loss. Neem is a plant known as botanical incesticide. This study tested the toxicity of neem cake against $A$. glycine and its effect on increasing tannin content in the soybean plant. The effect of neem cake extract to the mortality of A. glycine was tested by spray method and root dipping method. The application was carried out on four-week-old soybean plants with 10 individual of adult A. glycine as test insects. Observations were carried out every day for 8 DAT (day after treatmen) by counting the population of A. glycine. The testing of tannin levels and azadirachtin content is done by applying neem cake extract using root dipping method. The treatment is divided into two groups, which are infested plants and non-invested plants by A. glycine. The leaf of soybean (fourth day after application) was taken as samples for tannin and azadirachtin analysis. The results showed that the extract of neem cake at the spray method caused the death of A. glycine up to $97 \%$ at a concentration $2.5 \%$. The root dipping method could make mortality of nymphs (new born) $100 \%$ at concentrations of $0.1 \%$ and $0.125 \%$ at 8 DAT, but cannot make mortality to adult of A. glycine. The tannin content in soybean plants (with A. glycine and without A. glycine invested) was increased after $0.125 \%$ neem cake application. Azdirachtin uptake was not detected at concentrations of $0.125 \%$ and $0.250 \%$ at 5 DAT. Neem cake extract can suppress A. glycine population in soybean plants and increase of tannin content in plants. Keyword: neem cake extract, Aphis glycine, mortality, tannin
\end{abstract}

\section{ABSTRAK}

Toksisitas Ekstrak Ampas Biji Mimba (Azadirachta indica) terhadap Aphis glycine pada Tanaman Kedelai

Aphis glycine merupakan salah satu hama kedelai yang dapat berkembang dengan cepat hingga menyebabkan kehilangan hasil. Mimba termasuk sebagai tanaman yang berperan sebagai insektisida nabati. Penelitian ini menguji toksisitas ekstrak ampas biji mimba terhadap A. glycine serta pengaruhnya terhadap peningkatan kandungan tanin pada tanaman kedelai. Pengujian pengaruh ekstrak ampas bji mimba terhadap mortalitas A. glycie dilakukan dengan metode rendam akar dan metode semprot pakan. Aplikasi dilakukan tanaman kedelai umur 4 minggu dengan masing-masing 10 A. glycine dewasa sebagai serangga uji. Pengamatan dilakukan setiap hari selama 8 HSP (hari setalah perlakuan) dengan menghitung populasi A.glycine. Adapun pengujian terhadap kadar tanin dan azadirachtin dilakukan dengan mengaplikasikan ekstrak ampas biji mimba menggunakan metode rendam akar sesuai konsentrasi. Perlakuan terbagi kedalam dua kelompok yaitu tanaman yang diinvestasi dan tanaman yang tidak diinvestasi kutudaun. Pengambilan sampel daun untuk analisis tanin dilakukan pada hari keempat setelah aplikasi. Hasil pengujian menunjukkan bahwa ekstrak ampas biji mimba pada metode semprot pakan menyebabkan kematian A. glycine dewasa sebanyak 97\% pada konsentrasi 2,5\%. Metode rendam akar dapat mematikan populasi nimfa A. glycine yang baru muncul hingga mencapai $100 \%$ pada konsentrasi $0,1 \%$ dan $0,125 \%$ pada 8 HSP, namun tidak mematikan A. glycine dewasa. Kandungan tanin pada tanaman kedelai (dengan investasi A. glycine dan tanpa A. glycine) mengalami peningkatan setelah aplikasi ampas mimba $0,125 \%$, namun serapan azdirachtin tidak terdeteksi pada konsentrasi $0,125 \%$ dan $0,250 \%$ pada 5 HSP. Ampas biji mimba dapat menekan populasi A. glycine pada tanaman kedelai dan meningkatkan kandungan tannin.

Kata kunci: Ekstrak ampas biji mimba, Aphis glycnei, mortalitas, tanin

\section{Pendahuluan}

Kutudaun kedelai (Aphis glycine) merupakan salah satu hama kedelai. Hama ini dapat berkembang biak dalam koloni besar dan menyebabkan kehilangan hasil hingga 58\% (Wang et al., 1994). A. glycine banyak dijumpai pada permukaan bawah daun, namun juga menghisap cairan dari floem pada bagian batang, dan polong (Tilmon et al., 2011). Pada masa ini, penggunaan insektisida sintetik masih mendaji andalan petani sebagi usaha pengendalian hama tersebut. Namun, berbagai dampak negatif yang muncul seperti seperti pencemaran lingkungan, resistensi dan resurjensi serangga hama sasaran, terbunuhnya musuh alami serta adanya residu pada hasil panen. Mengingat banyaknya dampak negatif tersebut perlu dicari alternatif pengendalian lain yang ramah lingkungan.

Salah satu insektisida alami yang menjanjikan dan sudah lama diteliti adalah tumbuhan mimba (Azadirachta indica A. JUSS). Bagian tumbuhan mimba yang dapat dimanfaatkan sebagai insektisida diantaranya biji, daun, akar, kulit batang bahkan ampas biji mimba yang sudah diambil minyaknya masih bisa dimanfaatkan. Ampas biji mimba yang diaplikasikan ke tanah mempunyai manfaat ganda yaitu memperbaiki kandungan organik tanah dengan menyediakan hara makro dan mikro, dan juga dapat melindungi tanaman dari serangan hama. 
Azadirakhtin yang terkandung di dalam ampas biji mimba dapat mengakibatkan penurunkan populasi serangga hama. Hasil penelitian Rao (2002) menyebutkan bahwa pemberian ampas biji mimba ke tanah menyebabkan populasi hama Jassid empoasca dan Aphis craccivora lebih rendah dan kimiawi tanaman dengan kandungan nitrogen yang rendah, fenol dan tanin yang lebih tinggi dibandingkan dengan perlakuan yang diberi pupuk kimia. Ada korelasi antara perlakuan yang diberi ampas biji mimba dengan tingkat serangan hama dan kandungan nitrogen serta fenol dan tannin tanaman.

Pada penelitian ini diuji pengaruh ekstrak ampas biji mimba dan ampas biji mimba terhadap mortalitas dan perkembangan populasi A. glycine dan pengaruhnya terhadap kandungan tanin tanaman. Selain itu juga dianalisis serapan azadirakhtin pada tanaman kedelai. Tanin telah diketahui merupakan metabolisme sekunder yang berperan dalam pertahanan tanaman terhadap serangga herbivora.

\section{Bahan dan Metode}

Serangga uji yang digunakan adalah kutudaun A. glycine yang diambil dari tanaman kedelai di kebun percobaan Ciparanje, Universitas Padjadjaran. $A$. glycine yang didapat diidentifikasi dan langsung direaring didalam kurungan kassa. Kutudaun yang digunakan adalah A. glycine dewasa. Adapun varietas kedelai yang digunakan selama percobaan adalah varietas Anjasmoro, benih tersebut diperoleh dari Balai Penelitian Tanaman Aneka Kacang dan Umbi (BALITKABI) Semarang. Media tanam berupa campuran tanah dan pupuk kandang dengan perbandingan 2:1. Pada uji kelompok pertama menggunakan polybag ukuran $10 \times 15 \mathrm{~cm}$ dengan media tanam sebanyak $1200 \mathrm{~g}$ selanjutnya masingmasing polybag ditanam sebanyak dua benih kedelai. Ampas biji mimba yang digunakan pada penelitian ini diperoleh dari biji mimba yang berasal dari daerah Situbondo Jawa Timur. Ampas biji mimba ini merupakan produk akhir setelah dipres untuk diambil minyaknya. Ampas biji mimba berbentuk serpihan kasar dengan kandungan air 5\%.

Ekstraksi ampas biji mimba menggunakan metode maserasi dengan pelarut metanol $70 \%$ yang direndam selama 24 jam. Perbandingan ampas biji mimba dengan pelarut methanol $1: 4(\mathrm{w} / \mathrm{v})$. Larutan selanjutnya disaring dengan kertas waikman, kemudian dipisahkan antara pelarut dengan dan ekstrak dengan menggunakann ritari vacuum evaporator. Penelitian dilakukan di rumah kaca, Laboratorium Toksikologi dan Lingkungan Departemen Hama dan Penyakit Tumbuhan Fakultas Pertanian Universitas Padjadjaran. Analisis kandungan tanin dan polifenol dilakukan di Laboratorium Aplikasi Kimia dan Pelayanan, Fakultas MIPA Universitas Padjadjaran.

\section{Pengujian pengaruh ekstrak ampas bji mimba Metode semprot pakan terhadap A. glycine}

Pengujian menggunakan lima taraf konsentrasi + kontrol dan diulang 4 ulangan. Konsentrasi yang diuji yaitu 0,$50 ; 1,00 ; 1,50 ; 2,00$; dan $2,50 \%$. Daun kedelai yang digunakan untuk pengujian berumur 4 MST. daun kedelai disemprot hingga basah merata yang kemudian dikeringanginkan. Selanjutnya daun kedelai dimasukkan ke dalam cawan petri yang sebelumnya telah dialasi dengan kertas tissue, lalu $A$. glycine dewasa sebanyak 10 ekor dimasukkan ke petridist tersebut. Pengamatan dilakukan pada hari berikutnya selama 8 hari. Untuk menjaga kesegaran pakan, penggantian pakan dilakukan dengan menambahkan pakan segar pada hari kedua setelah aplikasi dan pergantian pakan dilakukan secara rutin pada hari berikutnya.

Pengamatan terhadap mortalitas diamati dengan cara menghitung jumlah populasi kutudaun yang hidup dan mati. Mortalitas diamati pada 24 jam setelah infestasi dan dilanjutkan sampai hari ke-8. Populasi kutudaun diamati dengan menghitung jumlah kutudaun yang berkembangbiak. Pengamatan populasi dilakukan terhadap masing-masing $A$. glycine yaitu populasi asal serangga uji dan populasi serangga baru (nimfa) yang muncul.

Pengujian pengaruh ekstrak ampas bji mimba terhadap A. glycine dengan metode rendam akar

Metode rendam akar dilakukan dengan cara tanaman kedelai yang berumur 4 MST dicabut dan dibersihkan dari tanah yang menempel pada akar, selanjutnya tanaman di masukkan ke dalam tabung reaksi ukuran $100 \mathrm{ml}$, yang sudah berisi $80 \mathrm{ml}$ larutan ekstrak ampas biji mimba yang diencerkan dengan akuades dengan lima taraf konsentrasi dan kontrol sebagai pembanding. Lima taraf konsentrasi yang diuji yaitu $0,025 \%, 0,050 \%, 0,075 \%, 0,100 \%, 0,125 \%$ Setelah tanaman direndam selama 24 jam, tanaman diinfestasikan dengan 10 kutudaun, selanjutnya tanaman disungkup dengan plastik mika silindris yang bagian atasnya ditutupi kain kasa.

Persentase mortalitas total kutudaun dihitung dengan menggunakan rumus sebagai berikut :

$\mathrm{MT}=\frac{b}{a+b} \quad \mathrm{x} 100 \%$

Keterangan :

MT $=$ Persentase mortalitas total

$\mathrm{a}=$ Jumlah serangga uji yang hidup

$\mathrm{b}=$ Jumlah serangga yang mati

\section{Pengujian pengaruh ekstrak ampas bji mimba yang diaplikasikan menggguakan metode rendam akar terhadap kandungan tannin tanaman}

Pengujian dilakukan pada tanaman kedelai umur 4 MST yang diaplikasikan dengan ekstrak ampas biji mimba (metode rendam akar yang dilakukan sama seperti pada penjelasan uji toksisitas) 
masing-masing perlakuan: kontrol, $0,125 \%$ dan $0,250 \%$ ekstrak ampas biji mimba dengan investasi dan tanpa investasi A. glycine. Pada tanaman perlakuan yang diinvestasi $A$. glycine dimasukan $A$. glycine sebanyak 10 ekor A. glycine dewasa pertanaman uji. Pada 4 hari setelah perlakuan, sampel daun diambil lalu dikeringkan menggunakan oven pada suhu $50^{\circ} \mathrm{C}$ dan selanjutnya digunakan sebagai sampel uji tannin.

Analisis kadar tanin menggunakan metode (JAOAC 35,225, 37,665 (1954). Daun kedelai kering sebagai sampel ditimbang sebanyak $1 \mathrm{~g}$ lalu dimasukkan ke dalam labu erlemeyer dan ditambahkan $80 \mathrm{ml}$ akuades, direfluks selama 30 menit. Hasil refluks dimasukkan ke dalam labu ukur $100 \mathrm{~mL}$ lalu ditambahkan $5 \mathrm{~mL}$ reagen Folin-Denis dan 10 ml larutan $\mathrm{Na}_{2} \mathrm{CO}_{3}$, selanjutnya ditambahkan akuades sampai tanda batas. Larutan dihomogenkan dan didiamkan selama 30 menit. Pembuatan larutan blanko dilakukan dengan cara yang sama hanya sampel di ganti dengan akuades. Absorbansi diukur menggunakan spekrtofotometri pada $760 \mu \mathrm{m}$ dan diplotkan dengan kurva standar.

\section{Analisis Serapan Azadirakhtin Pada Daun Kedelai}

Pengujian dilakukan pada tanaman kedelai umur 4 MST yang diaplikasikan dengan ekstrak ampas biji mimba (metode rendam akar yang dilakukan sama seperti pada penjelasan uji toksisitas) masing-masing perlakuan: kontrol, $0,125 \%$ dan $0,250 \%$ ekstrak ampas biji mimba. Analisis serapan azadirakhtin dilaukan pada daun tanaman kedelai yang direndam pada larutan ekstrak ampas biji mimba selama 5 hari. Selanjutnya daun kedelai dioven selama 12 jam pada suhu $50^{\circ} \mathrm{C}$, setelah itu daun kedelai diserbukkan dan di maserasi selama 24 jam dengan pelarut methanol, untuk mendapatkan ekstrak dilakukan ekstraksi dengan evaporator. Hasil ekstraksi akan diuji untuk melihat serapan azadiraktin pada daun tersebut menggunakan alat HPLC (High performance liquid Method) dengan fase gerak : Acetonitrile : Air $=65: 35$, Autosampler dengan flowrate : $1 \mathrm{ml} / \mathrm{menit}$, Colum : C.18, Detektor : UV, Waktu injek : 20 menit, volume injek : $20 \mu$ l.

\section{Hasil dan Pembahasan}

\section{Pengaruh aplikasi ekstrak ampas biji mimba metode semprot pakan terhadap kematian $A$. glycine}

Persentase kematian A. glycine setelah aplikasi esktrak ampas biji mimba meningkat sebanding dengan semakin tinggi konsentrasi yang digunakan. Perlakukan ekstrak ampas biji mimba yang diaplikasikan pada daun kedelai dapat mematikan $A$. glycine dewasa dan dapat menyebabkan penurunan nimfa yang terbentuk selama masa pengamatan 1-8 HSP. Hal ini dapat disebabkan karena pada metode semprot pakan, terjadi kontak langsung serangga uji dengan ekstrak ampas biji mimba.

Pada Tabel 1 dapat dilihat bahwa konsentrasi ekstrak ampas biji mimba 1,50\%, 2,00\%, 2,50\% dapat mematikan serangga uji berturut-turut $80,00 \%$, $95,00 \%$, dan $97,50 \%$ pada 8 HSP. Kematian yang diakibatkan oleh ekstrak ampas biji mimba lambat jika dibandingkan dengan insektisida sintetik. Pada uji ini dapat dilihat bahwa kematian A. glycine terus meningkat dari 2-8 HSP. Hasil analisis secara statistik juga menunjukkan bahwa perlakuan ekstrak ampas biji mimba konsentrasi 1,00\%, 1,50\%, 2\% dan 2,5\% berbeda nyata dengan kontrol pada pengamatan kelima hingga pengamatan kedelapan.

Tabel 1. Persentase kematian Aphis glycine setelah aplikasi ekstrak ampas biji mimba pada tanaman kedelai metode semprot pakan

\begin{tabular}{|c|c|c|c|c|c|c|}
\hline \multirow[t]{2}{*}{ Perlakuan } & \multicolumn{6}{|c|}{ Persentase kematian $A$. glicine pada (HSP) $(\mathrm{X} \pm \mathrm{SE})$} \\
\hline & $2 *$ & 4 & 5 & 6 & 7 & 8 \\
\hline Kontrol & $0,00 \pm 0,00$ & $10,00 \pm 0,00 \mathrm{a}$ & $10,00 \pm 0,00 \mathrm{a}$ & $10,00 \pm 0,00 \mathrm{a}$ & $15,00 \pm 2,89 \mathrm{a}$ & $15,00 \pm 2,89 \mathrm{a}$ \\
\hline $0,50 \%$ & $2,50 \pm 2,50$ & $12,50 \pm 4,78 \mathrm{a}$ & $20,00 \pm 0,00 \mathrm{ab}$ & $25,00 \pm 2,89 \mathrm{ab}$ & $30,00 \pm 4,08 \mathrm{a}$ & $47,50 \pm 6,29 \mathrm{~b}$ \\
\hline $1,00 \%$ & $2,50 \pm 2,50$ & $22,50 \pm 4,78 \mathrm{ab}$ & $25,00 \pm 6,45 b$ & $42,50 \pm 9,46 \mathrm{bc}$ & $57,50 \pm 8,53 b$ & $65,00 \pm 6,45 \mathrm{bc}$ \\
\hline $1,50 \%$ & $2,50 \pm 2,50$ & $32,50 \pm 4,78 b$ & $50,00 \pm 5,77 \mathrm{c}$ & $62,50 \pm 2,5 \mathrm{~cd}$ & $72,50 \pm 6,29 b$ & $80,00 \pm 9,13 \mathrm{~cd}$ \\
\hline $2,00 \%$ & $2,50 \pm 2,50$ & $35,00 \pm 2,88 \mathrm{~b}$ & $60,00 \pm 7,07 \mathrm{c}$ & $80,00 \pm 4,08 \mathrm{de}$ & $92,50 \pm 2,50 \mathrm{c}$ & $95,00 \pm 2,88 \mathrm{de}$ \\
\hline $2,50 \%$ & $5,00 \pm 2,88$ & $40,00 \pm 9,12 b$ & $62,50 \pm 4,78 \mathrm{c}$ & $85,00 \pm 6,45 \mathrm{e}$ & $95,00 \pm 2,88 \mathrm{c}$ & $97,50 \pm 2,5 \mathrm{e}$ \\
\hline $\begin{array}{ll}\mathrm{HSP} & : \mathrm{H} \\
\mathrm{X} & : \mathrm{ra} \\
\mathrm{SE} & : \mathrm{St} \\
\mathrm{PP} & : \mathrm{Pe} \\
\text { Angka } & \text { yan } \\
5 \% . & \\
* & : \text { tid }\end{array}$ & $\begin{array}{l}\text { ri setelah per } \\
\text { a-rata popula } \\
\text { ndar eror } \\
\text { sentase penu } \\
\text { diikuti huru } \\
\text { k bernengaru }\end{array}$ & $\begin{array}{l}\text { A. glycine } \\
\text { unan populas (p } \\
\text { yang sama pada } \\
\text { nyata }\end{array}$ & $\begin{array}{l}\text { ulasi kontrol-po } \\
\text { etiap kolom tida }\end{array}$ & $\begin{array}{l}\text { berbeda nyata } \\
\text { berlakuan) }\end{array}$ & $\begin{array}{l}\text { opulasi kontrol) } \\
\text { enurut uji Dunca }\end{array}$ & $\begin{array}{l}x 100 \% \\
\text { pada taraf nyata }\end{array}$ \\
\hline
\end{tabular}


Tabel 2. Parameter regresi probit hubungan konsntrasi dengan kematian A. glycine setelah aplikasi ekstrak metanol ampas biji mimba pada tanaman kedelai metode semprot pakan

\begin{tabular}{|c|c|c|c|c|c|c|}
\hline Perlakuan & $\mathrm{a} \pm \mathrm{SE}$ & $\mathrm{b} \pm \mathrm{SE}$ & $\mathrm{LC}_{50}$ & SK95\% & $\mathrm{LC}_{95}$ & SK $95 \%$ \\
\hline $5 \mathrm{HSP}$ & $-0,69 \pm 0,170$ & $2,44 \pm 0,614$ & 1,91 & $1,61-2,61$ & 8,99 & $5,33-48,52$ \\
\hline $6 \mathrm{HSP}$ & $-0,24 \pm 0,139$ & $2,97 \pm 0,54$ & 1,20 & $2,02-2,43$ & 4,30 & $3,25-8,24$ \\
\hline 7 HSP & $0,62 \pm 0,14$ & $3,52 \pm 0,60$ & 0,96 & $0,78-1,13$ & 2,83 & $2,31-4,32$ \\
\hline 8 HSP & $0,41 \pm 1,26$ & $2,97 \pm 0,58$ & 0,72 & $0,46-0,99$ & 2,60 & $1,92-8,26$ \\
\hline \multicolumn{3}{|l|}{ Keterangan: } & SE & \multicolumn{3}{|c|}{ : standar eror } \\
\hline & LC & \multicolumn{3}{|c|}{ : lethal concentration $(\%)$} \\
\hline \multicolumn{3}{|c|}{ kemiringan regresi } & SK & \multicolumn{3}{|c|}{ : selang Kepercayaan } \\
\hline
\end{tabular}

Kematian serangga uji mencapai $100 \%$ pada konsentrasi tertinggi menunjukkan bahwa ampas biji mimba yang diekstrak dengan air efetif dalam mengendalikan kutudaun A. glycine. Pavela et al (2004) menyebutkan bahwa efek yang diberikan dalam pengendalian kutudaun dengan aplikasi pada daun atau secara sistemik merupakan kombinasi dari efek antifeedan dan kemampuan bertahan hidup. . Penelitian Schneider et al. (2017) juga menunjukkan bahwa mimba dengan kandungan azadirakhtin 1.500 ppm dapat menurunkan jumlah telur dan jumlah telur yang berkembang pada Diatraea saccharalis. Mimba dapat meningkatkan kematian A. glycine, dengan meningkatkan waktu perkembangan aphid yang mencapai fase imago (Kraiss \& Cullen, 2008), gangguan pada proses molting, dan gangguan pada perkembangan ovarium (Pathak \& Tiwari, 2017).

Dari hasil uji didapatkan nilai $\mathrm{LC}_{50}$ dan $\mathrm{LC}_{95}$ pada 5, 6,7 dan 8 HSP berturut-turut adalah $1,91 \%$ dan $8,99 \% ; 1,20 \%$ dan $4,3 \% ; 0,96 \%$ dan $2,83 \% ; 0,72 \%$ dan 2,60\%. Nilai tersebut menunjukkan bahwa konsentrasi 2,60\% diharapkan dapat mematikan $95 \%$ serangga uji pada 8 hari setelah aplikasi (Tabel 2).

Pengaruh ekstrak ampas biji mimba dengan metode rendam akar terhadap $A$. glycine pada tanaman kedelai

Aplikasi ekstrak ampas biji mimba menggunakan metode rendam akar dapat menurunkan jumlah populasi nimfa $A$. glycine yang terbentuk. Pada penelitian ini, tidak ada imago A. glycine yang mati hingga 8 HSP (Hari Setelah Perlakuan). Persentase kematian nimfa $A$. glycine menunjukkan pada konsentrasi $0,1 \%$ dan $0,125 \%$ kematian nimfa mencapai $100 \%$, sedangkan pada konsentrasi $0,025 \%$ 0,075\% kematian nimfa A. glycine adalah 20\%-64\% pada 8 HSP (Tabel 3). Ekstrak ampas biji mimba yang diaplikasikan dengan cara rendam akar tidak dapat mematikan imago A. glycine yang diinvestasikan pada tanaman kedelai, namun dapat mematikan nimfa $A$. glycine yang terbentuk. Persentase kematian pada imago A. glycine yang nol menunjukkan bahwa pada metode rendam akar, zat toksik dari Azadirachtin tidak langsung mengakibatkan kematian pada serangga uji. Namun membuat keturunan dari serangga uji tersebut yang mengalami kematian. Hal tersebut sesuai dengan cara kerja insektisida mimba yang mengganggu proses reproduksi dan menyebabkan abnormalitas pada keturunan A. glycine hingga menyebabkan kematian. Seperti hasil penelitian Pavela et al. (2004) menyebutkan bahwa kandungan azadirachtin menyebabkan fertilitas kutudaun dewasa terganggu. Azadirachtin secara signifikan meningkatkan kematian nimfa dari kutudaun A. glycine (Kraiss \& Cullen, 2008).

Pada Tabel 4 terlihat adanya penurunan atau penambahan jumlah populasi $A$. glycine setelah aplikasi ampas mimba pada 2-8 HSP. Jika dibandingkan dengan kontrol, jumlah populasi $A$. glycine jauh lebih rendah. Pada $8 \mathrm{HSP}$, rata-rata populasi nimfa pada kontrol mencapai 71,25 ekor, sedangkan pada tanaman yang diaplikasikan ekstrak ampas biji mimba rata-rata populasi nimfa A. glycine adalah 0 hingga 19,25 ekor. Pada penelitian ini juga dapat dilihat bahwa mimba dapat menyebabkan penurunan jumlah keturunan dari A. glycine. Hasil penelitian Aziz et al. (2014) juga menunjukkan bahwa penyemprotan ampas biji mimba $(10 \%)$ pada tanaman Brassica napus L. dapat menurunkan populasi nimfa kutudaun Lipaphis erysimi dari 182,29 ekor menjadi 43,88 ekor (penurunan populasi 75,93\%) pada aplikasi pertama dan menurun kembali menjadi 25,28 ekor pada aplikasi kedua (penurunan populasi $86,13 \%)$. Penurunan populasi tersebut tentunya disebabkan karena kematian serangga uji yang diakibatkan oleh aplikasi mimba. Kraiss dan Eilen ( 2008 ) juga melaporkan bahwa penyemprotan minyak biji mimba dan azadirakhtin pada $A$. glycine dapat menyebabkan kematian nympha $80 \%$ oleh azadirakhtin dan $77 \%$ oleh minyak mimba.

Cara aplikasi yang berbeda menyebabkan pengaruh yang berbeda terhadap A. glycine. Meskipun pada akhirnya tetap terjadi penurunan populasi karena adanya $A$. glycine yang mati. Namun, dari perbedaan tersebut dapat diketahui cara kerja mimba dalam mengendalikan A. glycine. Pada aplikasi ampas biji mimba dengan dicampurkan pada media tanam dapat menurunkan populasi $A$. glycine jauh lebih rendah dari kontrol (Tabel 4). Pada metode ini dapat dilihat bahwa penurunan populasi terjadi setelah peningkatan populasi pada 1-2 MSP. Jumlah populasi yang selalu lebih rendah dari kontrol juga menunjukkan bahwa pertambahan populasi A. glyine setelah aplikasi menjadi lebih rendah. 
Tabel 3. Persentase kematian keturunan Aphis glycine (Nimfa) setelah aplikasi ampas biji mimba pada tanaman kedelai metode rendam akar

\begin{tabular}{lrrrrrrrr}
\hline \multirow{2}{*}{ Perlakuan } & \multicolumn{8}{c}{ \% kematan nimfa pada (HSP) } \\
\cline { 2 - 9 } & 1 & 2 & 3 & 4 & 5 & 6 & 7 & 8 \\
\hline Kontrol & 0,0 & 0,0 & 0,0 & 1,6 & 3,1 & 5,6 & 13,9 & 20,6 \\
$0,025 \%$ & 0,0 & 0,5 & 1,5 & 3,6 & 5,7 & 13,1 & 24,7 & 30,8 \\
$0,050 \%$ & 0,0 & 1,8 & 9,3 & 18,5 & 19,5 & 24,5 & 45,0 & 64,5 \\
$0,075 \%$ & 0,0 & 3,6 & 12,7 & 31,6 & 30,6 & 37,4 & 47,6 & 62,6 \\
$0,100 \%$ & 0,0 & 1,6 & 10,8 & 28,4 & 32,8 & 44,0 & 94,4 & 100,0 \\
$0,125 \%$ & 0,0 & 4,3 & 25,0 & 43,7 & 42,7 & 56,3 & 87,9 & 100,0 \\
\hline
\end{tabular}

Tabel 4. Populasi keturunan Aphis glycine (nimfa) setelah aplikasi ampas biji mimba pada tanaman kedelai metode rendam akar

\begin{tabular}{|c|c|c|c|c|c|c|c|c|}
\hline \multirow{3}{*}{ Perlakuan } & \multicolumn{8}{|c|}{ Rata-rata populasi nimfa A. glicine pada (HSP) } \\
\hline & \multicolumn{2}{|l|}{2} & \multicolumn{2}{|c|}{4} & \multicolumn{2}{|c|}{6} & \multicolumn{2}{|l|}{8} \\
\hline & $(\mathrm{X} \pm \mathrm{SE})$ & PP & $(\mathrm{X} \pm \mathrm{SE})$ & PP & $(\mathrm{X} \pm \mathrm{SE})$ & PP & $(\mathrm{X} \pm \mathrm{SE})$ & PP \\
\hline Kontrol & $28,5 \pm 4,21 \mathrm{~b}$ & - & $77,00 \pm 6,6 \mathrm{~d}$ & - & $84,75 \pm 9,72 \mathrm{c}$ & - & $71,25 \pm 7,81 \mathrm{c}$ & - \\
\hline $0,025 \%$ & $16,75 \pm 0,75 a$ & 41,23 & $53,75 \pm 10,29 \mathrm{c}$ & 30,19 & $38,00 \pm 6,09 b$ & 55,16 & $12,00 \pm 1,08 b$ & 83,15 \\
\hline $0,050 \%$ & $14,00 \pm 1,08 \mathrm{a}$ & 50,88 & $29,75 \pm 4,49 b$ & 61,36 & $37,75 \pm 4,36 b$ & 55,46 & $17,75 \pm 0,75 b$ & 75,08 \\
\hline $0,075 \%$ & $13,25 \pm 2,21 \mathrm{a}$ & 53,51 & $26,50 \pm 4,76 \mathrm{ab}$ & 65,58 & $32,25 \pm 4,23 b$ & 61,95 & $19,25 \pm 7,00 b$ & 72,98 \\
\hline $0,100 \%$ & $15,5 \pm 2,59 a$ & 45,61 & $31,50 \pm 2,25 b$ & 59,09 & $32,50 \pm 0,96 b$ & 61,65 & $0,00 \pm 0,00 \mathrm{a}$ & 100 \\
\hline $0,125 \%$ & $11,25 \pm 1,49 a$ & 60,53 & $20,00 \pm 2,48 \mathrm{a}$ & 74,03 & $23,35 \pm 3,72 \mathrm{a}$ & 72,56 & $0,00 \pm 0,00 \mathrm{a}$ & 100 \\
\hline
\end{tabular}

Keterangan:

HSP : Hari setelah perlakuan

$\mathrm{X}$ : rata-rata populasi A. glycine

SE : Standar eror

PP : Persentase penurunan populas (populasi kontrol-populasi perlakuan)/populasi kontrol) x100\%

Angka yang diikuti huruf yang sama pada setiap kolom tidak berbeda nyata menurut uji Duncan pada taraf nyata $5 \%$.

* : tidak berbeda nyata

Hasil uji menggunakan metode rendam akar tersebut menunjukkan bahwa imago awal yang diinvestasi tidak mengalami kematian namun mempengaruhi jumlah nimfa keturunan yang terbentuk. Nimfa yang terbentuk setelah aplikasi ekstrak ampas biji mimba jauh lebih rendah dibandingkan kontrol. Hal tersebut memperlihatkan bahwa kerja mimba juga mempengaruhi reproduksi serangga dengan menurunnya jumlah keturunan yang terbentuk. Azadirachtin memberikan efek antifidan yang menggangu rangsangan untuk makan (Mordue et al., 1998) serta pada kutudaun dapat menurunkan umur nimfa, dan meingkatkan kematian hama (Pavela et al., 2004).

Efek kontak dari ekstrak mimba juga dapat dilihat pada metode semprot pakan. Pada metode tersebut, A. glycine terkena langsung oleh ekstrak ampas mimba baik dari residu yang tersisa atau dari efek sistemik mimba. Sehingga imago A. glycine yang diinvestasi mengalami kematian sesuai konsentrasi yang digunakan. Berbeda dengan metode rendam akar yang tidak dapat mematikan imago A.glycine. Kerja sistemik dari mimba yang terabsorpsi kedalam tanaman dan tersebar ke jaringan tanaman akan menyebabkan pengaruh pada serangga-serangga dengan tipe mulut menghisap (Senthil-Nathan et al., 2007; Pavela et al., 2004). Kerja sistemik ini juga ditemui pada ampas mimba seperti hasil penelitian Saxena et al., (1987) \& Roychoudhury (2016) yang menunjukkan adanya efek antifidan sistemik dari ekstrak air ampas mimba sebagai produk yang memiliki sifat baik sebagai antifidan dan penghambat pertumbuhan.

Dari kedua metode aplikasi tersebut dapat diketahui bahwa ampas biji mimba ataupun ekstraknya dapat digunakan untuk mengendalikan $A$. glycine. Menurut Sundaram et al. (1995) formulasi mimba yang mengandung azadirakhtin-A yang diaplikasikan ke tanah disekitar perakaran pada tanaman aspen yang ditanam di dalam pot, menunjukkan hasil senyawa azadirakhtin diserap oleh akar dalam waktu 3 jam dan ditranslokasikan ke batang dan daun dalam 3 hari. Rao (2003) melaporkan bahwa penanaman kacang tanah organik dengan pemberian ampas mimba dengan dosis 8 ton/ha, ampas biji mimba $770 \mathrm{~kg} / \mathrm{ha}$ dan kascing 3,75 ton/ha menyebabkan populasi Spodoptera litura terendah dibandingkan dengan pemberian NPK. Selain itu, hasil penelitian Sinha et al. (2017) menunjukkan bahwa aplikasi ampas nimba $2 \mathrm{kw} / \mathrm{ha}$ dan $5 \mathrm{kw} / \mathrm{ha}$ dapat menurunkan populasi kutudaun Lipaphis erysimi sebanyak $22,36 \%$ dan $37,31 \%$. 
Analisis kandungan tanin dan azadirakhtin pada daun kedelai setelah aplikasi ekstrak ampas biji mimba metode rendam akar

Hasil penelitian menunjukkan bahwa perlakuan ekstrak ampas biji mimba mampu meningkatkan kandungan tanin pada tanaman kedelai pada konsentrasi $0,125 \%$ dan $0,250 \%$ dengan Investasi A. glycine (Tabel 5). Hal tersebut menunjukkan bahwa aplikasi ekstrak ampas biji mimba mampu menginduksi produksi tanin lebih tinggi ketika tanaman mendapatkan serangan dari $A$. glycine. Sumber yang paling banyak mengandung tanin adalah organ reproduksi seperti biji dan buah (Constabel et al., 2014). Selain kandungan tanin yang sudah ada pada tanaman, dengan penambahan tanin dari luar diharapkan dapat meningkatkan kandungan tanin pada tanaman tersebut. Tanin dapat diisolasi menggunakan pelarut etanol dan methanol. A. indica mengandung senyawa alkaloid, steroid, saponin, tannin, dan flavonoid jika diesktraksi menggunakan etanol dan methanol (Zainab \& Hossain, 2016; Susmitha et al., 2013).

Hasil uji menggunakan metode rendam akar selama 5 hari menunjukkan bahwa tidak terlihat adanya azadirakhtin yang terserap pada daun kedelai setelah aplikasi esktrak ampas biji mimba dengan metode rendam akar konsentrasi $0,125 \%$ dan $0,25 \%$ (Tabel 5, Gambar 1). Pada Gambar 1 tidak terlihat adanya puncak pada waktu menit ke-20. Hal tersebut kemungkinan terjadi karena rendahnya serapan azadirakhtin yang terkandung dalam ekstrak tersebut oleh perakaran tanaman. Hal tersebut berbeda dengan hasil penelitian Sundaram et al. (1995) menyebutkan azadirakhtin dapat ditranslokasikan dalam waktu 3 hari. Tidak terdeteksinya azadirakhtin dari ekstrak ampas mimba kemungkinan disebabkan karena rendahnya kandungan azadirakhtin dari ekstrak ampas biji mimba yang terserap tanaman hingga tertranslokasi sampai ke daun. Kandungan azadirakhtin yang rendah karena ampas merupakan sisa dari pengepresan biji mimba yang merupakan tempat terbanyak kadar azadirakhtin. Kadar azadirakhtin pada ampas biji mimba hanya 0,079$0,185 \mathrm{mg} / \mathrm{g}$ (Nicoletti et al ., 2012), sedangkan pada biji mimba kandungan azadiarchtin mencapai 0,4-3,09 $\mathrm{mg} / \mathrm{g}$ (Elteraifi \& Hassanali, 2011).

Walaupun di daun tidak terdeteksi serapan azadirakhtin, aplikasi ampas biji mimba metode rendam akar mampu menurunkan populasi nimfa $A$. glycine seperti pada paparan sebelumnya. Hal tersebut menunjukkan bahwa pada metode rendam akar komponen tannin yang lebih berperan. Komponen tanin sebagai pertahanan tanaman terhadap serangga dengan cara menghalangi serangga dalam mencerna makanan. Tanin dapat mengganggu serangga dalam mencerna makanan karena tanin akan mengikat protein dalam proses penyerapan protein dalam sistem pencernaan yang diperlukan serangga untuk pertumbuhan sehingga penyerapan protein dalam sistem pencernaan menjadi terganggu.

Tanin adalah metabolit sekunder yang merupakan faktor penting pada pertahanan tanaman terhadap serangga herbivor. Tanin memiliki zat yang membuat rasa pahit yang dapat menghambat serangga untuk makan (War et al., 2018). Tanin yang teroksidasi digunakan sebagai mekanisme untuk pertahanan tanaman. Tanin aktif yang teroksidasi memiliki fungsi seperti alkalin pada mesenteron (perut tengah) beberapa serangga (Salminen \&Karonen, 2011). Tanin mengikat protein serangga pada mesenteron dan enzim pencernaan dan mengendapkannya melalui ikatan hidrogen atau kovalen, sehingga membatasi ketersediaannya bagi serangga dan pada akhirnya mengurangi pertumbuhan dan perkembangan serangga (Arnold \& Schultz 2002; Peters \& Constabel 2002; War et al. 2012). Selanjutnya, tanin mengkelat ion logam dan menghasilkan lesi pada mesenteron serangga (Barbehenn \& Constabel 2011).

Tabel 5. Hasil analisis kandungan tanin dan serapan azadirakhtin pada daun kedelai setelah aplikasi ekstrak ampas biji mimba

\begin{tabular}{lcc}
\hline \multicolumn{1}{c}{ Perlakuan } & Kandungan Tanin (\%) & Serapan azadirakhtin (\%) \\
\hline Kontrol + A.glycine & 1,448 & - \\
Kontrol tanpa A.glycine & 1,543 & - \\
$0,125 \%$ ekstrak + A.glycine & 1,733 & 0 \\
$0,125 \%$ ekstrak tanpa A.glycine & 2,131 & - \\
$0,250 \%$ ekstrak + A.glycine & 1,521 & 0 \\
$0,250 \%$ tanpa A.glycine & 1,524 & - \\
\hline
\end{tabular}

Keterangan

- : analisis tidak dilakukan 


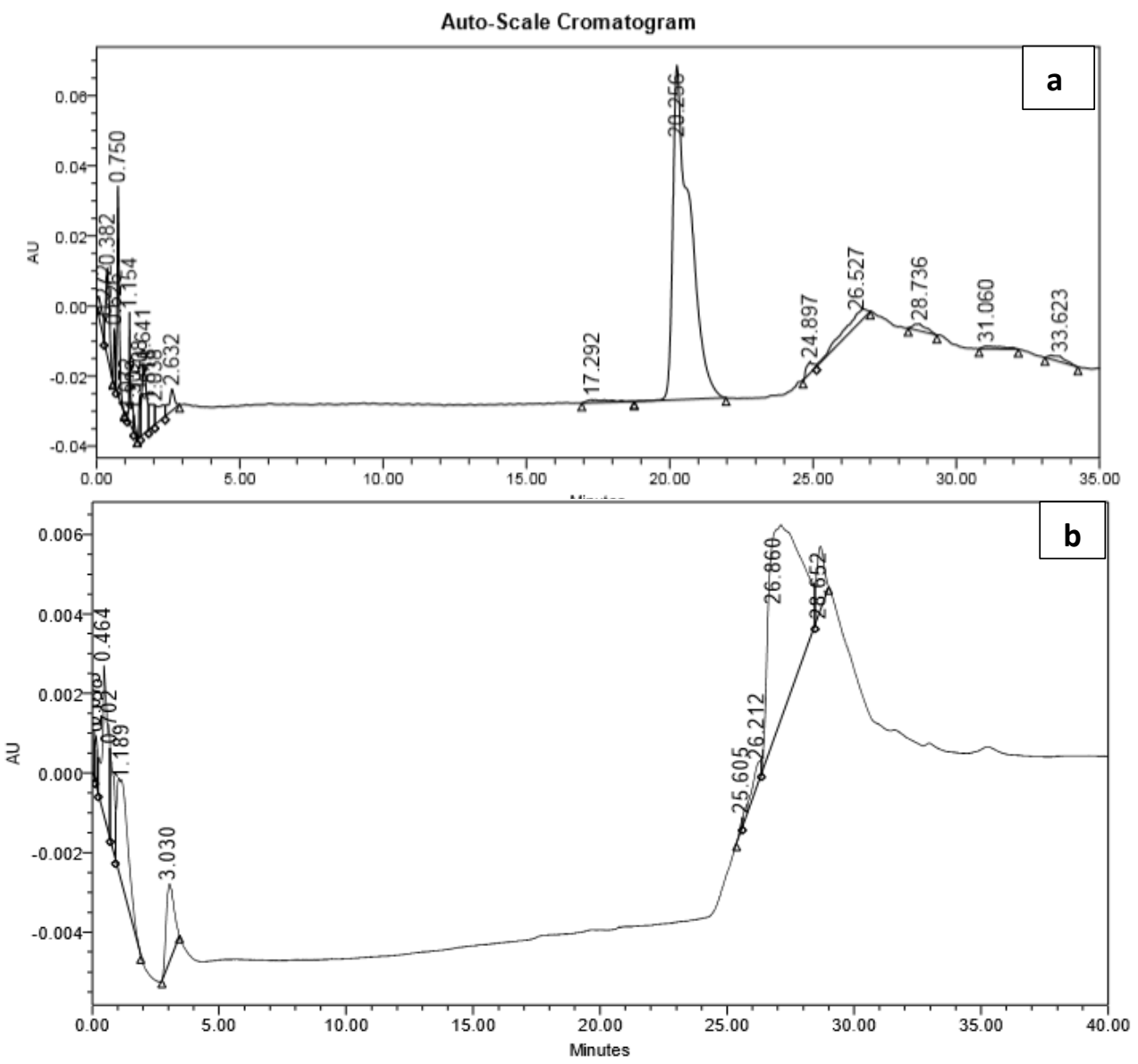

Gambar 1. Kromatogram analisis HPLC (a : Azadirachtin standar, puncak terlihat pada menit ke-20 b : perlakuan dengan rendam akar pada larutan ekstrak ampas biji mimba konsentrasi 0,250\%, tidak terdeteksi adanya azadirakhtin pada menit ke-20)

\section{Kesimpulan}

Ekstrak ampas biji mimba yang diaplikasikan dengan metode rendam akar dapat menurunkan jumlah populasi nymfa $A$. glycine yang muncul, namun tidak mengakibatkan pada A. glycine dewasa. Ekstrak ampas biji mimba yang diaplikasikan dengan metode semprot pakan dapat mematikan serangga uji hingga $97 \%$ pada pakan yang disemprot ekstrak ampas biji mimba $(2,5 \%)$. Hasil uji kandungan tanin juga menunjukkan bahwa aplikasi ampas mimba konsentrasi $0,125 \%$ dapat meningkatkan kandungan tanin pada tanaman kedelai. Pada penelitian ini serapan azdirachtin tidak terdeteksi pada 5 hari setelah perlakuan rendam akar.

\section{Daftar Pustaka}

Arnold TM \& JC. Schultz. 2002. Induced sink strength as a prerequisite for induced tannin biosynthesis in developing leaves of Populus. Oecologia 130:585-593

Aziz, MA., RS Ali., N. Muhammad, \& S. Ghulam. 2014. Evaluation of different neem products in comparison with imidacloprid against different morphs of mustard aphid Lipaphis erysimi kalt.) on canola crop. Asian J Agri Biol, 2014, 2(3):191-201.

Barbehenn, RV \& PC. Constabel. 2011. Tannins in plant-herbivore interactions. Phytochemistry 72:1551-1565

Constabel, CP., K. Yoshida, \& V. Walker. 2014. Diverse Ecological Roles of Plant Tannins: Plant Defense and Beyond. John Wiley \& Sons. 115-142. DOI: 10.1002/ 9781118329634.ch

Elteraifi, IE \& A. Hassanali. 2011. Oil and azadirachtin contents of neem (azadirachta indica A. Juss) seed kernels collected from trees growing in different habitats in Sudan. Int J. Biol. Chem. Sci. 5(3):1063-1072.

Kraiss, H \& EM. Cullen. 2008. Insect growth regulator effects of azadirachtin and neem oil on survivorship, development and fecundity of Aphis glycines (Homoptera: Aphididae) and its predator, Harmonia axyridis (Coleoptera: Coccinellidae). Pest Manag Sci 64:660-668 (2008)

Kraiss, H., \& M.Eileen. 2008. Insect growth regulator effects of azadirachtin and neem oil on survivorship, development and fecundity of 
Aphis glycines (Hemiptera: Aphididae) and its predator, Harmonia axyridis (Coleoptera: Coccinellidae). Journal Pest Management Sciences, Society of Chemical Industry.

Mordue, A. J., Simmonds, M. S. J., Ley, S. V., Blaney, W. M., Mordue, W., Nasiruddin, M., and Nisbet, A. J. 1998. Actions of azadirachtin, a plant allelochemical, against insects. Pesticide Science, 54(3), 277-284. https://doi.org/10.1002/(SICI)10969063(1998110)54:3<277::AIDPS801>3.0.CO;2-I

Nicoletti, M., M. Susanna, M. Oliviero, C. Tiziana \& M. Kardaray. 2012. Neem cake: Chemical composition and larvicidal activity on Asian tiger mosquito Parasitol Res. 111:205-213. DOI 10.1007/s00436-012-2819-8

Pathak, CS., \& SK Tiwari. 2017. potential of neem seed's acetone extract on the haemolymph and fat biochemistry of Cocyra cephalonica larvae (Lepidoptera: Pyralidae). Journal Adv. Zoologi, 38(2), 164-177.

Pavela, R., M. Barnet \& F. Kocourek 2004. Effect of applied systemically through roots of plant on the mortality, development and fecundity of the cabbage aphid (Brevicoryne brassicae). Phytoparasitica 32(3) : 286-294

Peters DJ, \& CP. Constabel. 2002. Molecular analysis of herbivoreinduced condensed tannin synthesis: cloning and expression of dihydroflavonol reductase from trembling aspen (Populus tremuloides). The Plant Journal: for Cell and Molecular Biology 32:701-712

Rao, K.R, 2002, Influence of Host plant resistance in the management of sucking insect pest of groundnut. Ann. Pl. Protec. Sci., 10(1): 45-50.

Rao, K.R, 2003, Influence of host plant nutrition on the incidence of Spodoptera litura (Fab) and Helicoverpa armigera (Hub.) on groundnut. Indian J. Entomol., 65:386-392.

Roychoudhury, R. 2016. Neem Products. In Ecofriendly Pest Management for Food Security. 2016 Elsevier Inc. All rights reserved. http://dx.doi.org/10.1016/B978-012-803265-7.00018-X

Susmitha, K.K. Vidyamol, P. Ranganayaki \& R. Vijayaragavan. 2013. Phytochemical Extraction and Antimicrobial Properties of Azadirachta indica (Neem). Global Journal of Pharmacology. 7 (3): 316-320. DOI: 10.5829/idosi.gjp.2013.7.3.1107

Salminen, JP. \& M. Karonen. 2011. Chemical ecology of tannins and other phenolics: we need a change in approach. Functional Ecology. 25, 325-338 doi: 10.1111/j.13652435.2010.01826.x
Saxena, RC., R. Khan, \& NB. Bajet, 1987. Reduction of Tungro Virus Transmission by Nephotettix virescens (Homoptera: Cicadellidae). Journal of Economic Entomology, 80(5), 1079-1082.

Schneider, L. C. L., CV. daSilva, \& H. Conte. 2017. Toxic effect of commercial formulations of neem oil, Azadirachta indica A. Juss., in pupae and adults of the sugarcane borer, Diatraea saccharalis F. (Lepidoptera: Crambidae). Arq. Inst. Biol, 84(0), 1-8. https://doi.org/10.1590/1808-1657000432014

Senthil NS., MY. Choi, CH. Paik, HY. Seo, JD. Kim, \& SM. Kang. 2007. The toxic effects of neem extract and azadirachtin on the brown planthopper, Nilaparvata lugens (Stål) (BPH) (Homoptera: Delphacidae). Chemosphere, 67(1), 80-88. https://doi.org/ 10.1016/ j.chemosphere .2006.09.045

Sinha, R., B. Singh, P.K. Rai, A. Kumar, S. Jamwal, \& B.K. Sinha. 2018. Soil fertility management and its impact on mustard aphid, Lipaphis erysimi (Kaltenbach) (Hemiptera: Aphididae). Cogent Food \& Agriculture (2018), 4: 1450941. https://doi.org/10.1080/ 23311932. 2018.1450941

Sundaram, KMS., R. Campbell, L. Sloane, \& J. Studens, 1995. Uptake, translocation and persistence and fate of azadirachtin in aspen plants (Papolus tremuloides Michx.) and its effect on pestiferous two-spotted spider mite (Tetranychus urticae Koch). Crop Protection. 14 (5) : 415-421

Tilmon, K.J., EW. Hodgson, ME. O’Neal, \& DW. Ragsdale,. 2011. Biology of the Soybean Aphid, Aphis glycines (Hemiptera: Aphididae) in the United States. J. Integ. Pest Mngmt. 2(2): 2-7.

Wang, X.B., Fang, Y.H., Lin, S.Z., Zhang, L.R., \& Wang, H.D. 1994. A Study on the damage and economic threshold of the soybean aphid at the seedling stage. Plant Prot 20:12-13.

War AR, MG. Paulraj, T. Ahmad, AA. Buhroo, B. Hussain, S. Ignacimuthu, \& HC. Sharma. 2012. Mechanisms of plant defense against insect herbivores. Plant Signaling \& Behavior 7:1306-1320

War AR, GK. Taggar, B. Hussain, MS. Taggar, RM. Nair, \& HC. Sharma. 2018. Plant defence against herbivory and insect adaptations. $A o B$ PLANTS 10:1-19. ply037; doi: 10.1093/aobpla/ply037

Zainab SSA \& MA. Hossain. 2016. Biological activities of different neem leaf crude extracts used locally in Ayurvedic medicine. Pacific Science Review A: Natural Science and Engineering xxx (2016) 1e4

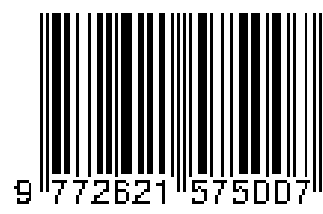

